\title{
In vivo functional expression of a screened $P$. aeruginosa chaperone-dependent lipase in $E$. coli
}

\author{
Xiangping $\mathrm{Wu}^{\dagger}$, Pengyong $\mathrm{You}^{\dagger}$, Erzheng Su${ }^{*}$, Jingjing $\mathrm{Xu}$, Bei Gao and Dongzhi Wei
}

\begin{abstract}
Background: Microbial lipases particularly Pseudomonas lipases are widely used for biotechnological applications. It is a meaningful work to design experiments to obtain high-level active lipase. There is a limiting factor for functional overexpression of the Pseudomonas lipase that a chaperone is necessary for effective folding. As previously reported, several methods had been used to resolve the problem. In this work, the lipase (LipA) and its chaperone (LipB) from a screened strain named AB which belongs to Pseudomonas aeruginosa were overexpressed in E. coli with two dual expression plasmid systems to enhance the production of the active lipase LipA without in vitro refolding process.
\end{abstract}

Results: In this work, we screened a lipase-produced strain named AB through the screening procedure, which was identified as $P$. aeruginosa on the basis of $16 \mathrm{~S}$ rDNA. Genomic DNA obtained from the strain was used to isolate the gene lipA (936 bp) and lipase specific foldase gene lipB (1023 bp). One single expression plasmid system E. coli BL21/pET28a-lipAB and two dual expression plasmid systems E. coli BL21/pETDuet-lipA-lipB and E. coli BL21/ pACYCDuet-lipA-lipB were successfully constructed. The lipase activities of the three expression systems were compared to choose the optimal expression method. Under the same cultured condition, the activities of the lipases expressed by E. coli BL21/pET28a-lipAB and E. coli BL21/pETDuet-lipA-lipB were $1300 \mathrm{U} / \mathrm{L}$ and $3200 \mathrm{U} / \mathrm{L}$, respectively, while the activity of the lipase expressed by E. coli BL21/pACYCDuet-lipA-lipB was up to $8500 \mathrm{U} / \mathrm{L}$. The lipase LipA had an optimal temperature of $30^{\circ} \mathrm{C}$ and an optimal $\mathrm{pH}$ of 9 with a strong $\mathrm{pH}$ tolerance. The active LipA could catalyze the reaction between fatty alcohols and fatty acids to generate fatty acid alkyl esters, which meant that LipA was able to catalyze esterification reaction. The most suitable fatty acid and alcohol substrates for esterification were octylic acid and hexanol, respectively.

Conclusions: The effect of different plasmid system on the active LipA expression was significantly different. pACYCDuet-lipA-lipB was more suitable for the expression of active LipA than pET28a-lipAB and pETDuet-lipA-lipB. The LipA showed obvious esterification activity and thus had potential biocatalytic applications. The expression method reported here can give reference for the expression of those enzymes that require chaperones.

Keywords: Pseudomonas aeruginosa, Lipase, Chaperone, Dual expression plasmid, Esterification

\section{Background}

Lipases (triacylglycerol acylhydrolases, EC 3.1.1.3) catalyze the hydrolysis and synthesis of a variety of acylglycerols at the interface of lipid and water [1]. Owing to the properties like wide substrate specificity, high enantio- and regioselectivity, lipases have a wide range of potential applications in industry such as organic synthesis,

\footnotetext{
* Correspondence: ezhsu@ecust.edu.cn; dzhwei@ecust.edu.cn

${ }^{\dagger}$ Equal contributors

State Key Laboratory of Bioreactor Engineering, New World Institute of Biotechnology, East China University of Science and Technology, Shanghai 200237, China
}

(c) 2012 Wu et al.; licensee BioMed Central Ltd. This is an Open Access article distributed under the terms of the Creative Commons Attribution License (http://creativecommons.org/licenses/by/2.0), which permits unrestricted use, distribution, and reproduction in any medium, provided the original work is properly cited. detergent formulation, food and pharmaceutical industries [2,3]. Pseudomonas lipases display special biochemical characteristics which are not common among the lipases produced by other microorganism. For example, it has exhibited amide hydrolyzing activity [4] and high enantioselectivity towards hydrolysis of racemic esters $[5,6]$.

In spite of various potential applications of Pseudomonas lipases, their functional overexpression requires a lipase-specific chaperone to fold into an active conformation $[7,8]$. Although the lipases can be produced by their homologous expression in Pseudomonas hosts, 
many Pseudomonas strains are potential pathogens and special safety regulations need to govern their cultivation. Therefore, it is necessary to set up a heterologous expression system and develop efficient refolding procedure.

Recent years, many microbial lipase genes had been isolated, cloned, sequenced and overexpressed in homologous or heterologous hosts such as Escherichia coli, filamentous fungi or yeast. The expression of recombinant proteins in bacteria hosts often results in the formation of inclusion bodies which are insoluble and inactive. Many methods had been used to obtain high active expression amount of Pseudomonas lipases [9-12]. The amount of active enzyme achieved by co-expression of Pseudomonas lipase and its cognate foldase in an expression vector was low because of the complexity of the gene regulatory and secretion mechanisms [13-15]. Therefore, two expression vectors had been used to solve this problem. For example, Madan B and Mishra P [16] put the lipA and $\operatorname{lip} B$ under the influence of strong T7 promoter in $\mathrm{pET} 32 \mathrm{Xa} / \mathrm{LIC}$ and $\mathrm{pET} 29 \mathrm{a}$ vectors, respectively. Then E. coli BL21 (DE3) containing pETlipA and pETlipB was expressed upon induction with IPTG, and the productivity attained to $812 \mathrm{U} \mathrm{L}^{-1} \mathrm{~h}^{-1}$. Akbari et al. [17] also subcloned the lipase and lipase specific foldase into two separate expression vectors and expressed in E. coli as inactive inclusion bodies and soluble form, respectively. Then the lipase and lipase special foldase were mixed in vitro to refold active lipase. The effect of different concentrations of various additives on the lipase refolding was investigated, and the best yield of $70 \mathrm{IU} / \mathrm{ml}$ was obtained.

In this work, a lipase-producing strain was screened from oil-rich soil and identified as Pseudomonas aeruginosa through $16 \mathrm{~S}$ rDNA sequence analysis. Then the lipase gene $\operatorname{lip} A$ and the lipase special foldase gene $\operatorname{lip} B$ were successfully cloned and sequenced. The expression vectors pACYCDuet-1 and pETDuet-1 containing two multiple cloning sites (MCS) were used to co-express the two target genes. In vivo expression of the active lipase was successfully achieved. To date, only one report by Quyen et al. [18] achieved the expression of in vivo functional lipase in heterologous host $E$. coli using a dual expression plasmid system which was derived from pET22b. It demonstrated that a dual expression plasmid system $E$. coli could overproduce and secrete the active chaperone-dependent lipase (subfamilies I.1 and I.2) in vivo. An improved dual expression plasmid system E. coli could be potentially applied for industrial-scale production of subfamily I.1 and I.2 lipases.

\section{Results and discussion}

\section{Identification of the lipase-producing strain}

Initially, one isolate named $A B$ from oil-rich samples enriched on Rhodamine B agar plates was selected through the screening procedure. For precise identification, 16S rRNA gene sequencing of the isolate was performed and nucleotide sequence generated was aligned and analyzed for identification of bacterial species. Through the phylogenetic tree analysis, 16S rRNA gene sequence of strain $\mathrm{AB}$ was compared with the sequences of ten Pseudomonas species. This strain had a high degree of homology (99\% 16S rRNA gene sequence similarity) with Pseudomonas aeruginosa (Figure 1), and thus was identified as Psedomonas aeruginosa.

\section{Cloning and sequence analysis of lipase and lipase foldase genes from strain $A B$}

Genomic DNA obtained from the strain $\mathrm{AB}$ was used to isolate the lipase and lipase specific foldase genes. The lipase gene named lipA consisted of 936 nucleotides, encoding 311 amino acids, and the size of lipase specific foldase gene named lipB was $1023 \mathrm{bp}$, encoding 340 amino acids. Both genes had 99\% homology with reported sequences that from Pseudomonas aeruginosa PAO1 (AE004091.2) or Pseudomonas aeruginosa lip9 (AB290342.1). The gene lipA had nine nucleotides different from that of Pseudomonas aeruginosa PAO1, but

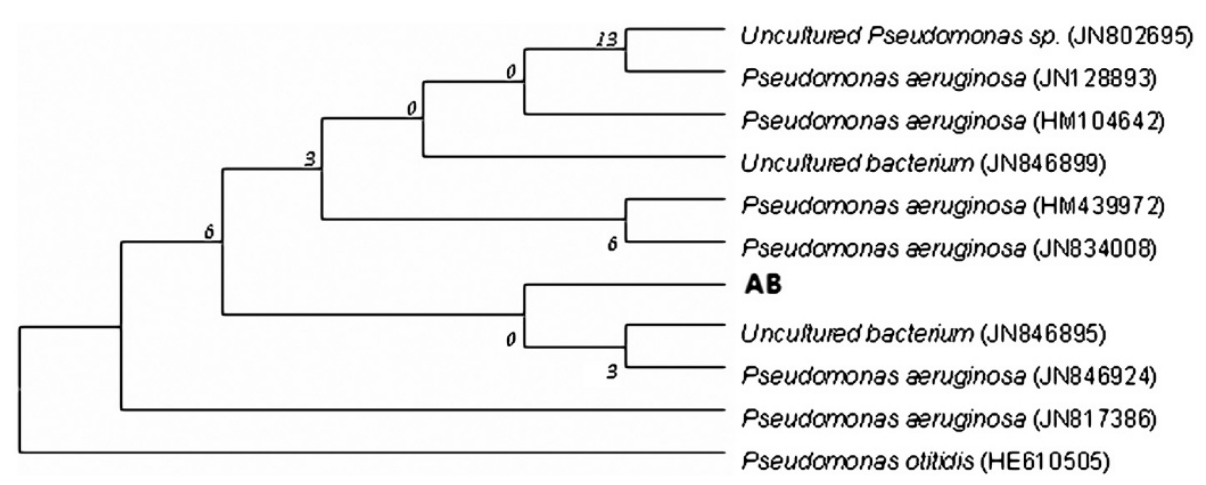

Figure 1 Phylogenetic analysis by $16 \mathrm{~S}$ rRNA gene sequencing of strain AB. Phylogenetic analysis was performed using the program MEGA4.0. The length of each branch pair represents the evolutionary distance between the sequences. 
only one amino acid was different (Lys was replaced by Arg). The gene lipB which encoded lipase-specific chaperone was coexpressed along with the structure gene of lipA in the same operon in P.aeruginosa. The gene $\operatorname{lip} A B$ which contained both $\operatorname{lip} A$ and $\operatorname{lip} B$ consisted of 2008 nucleotides, and there were 49 bp between lipA and lipB. The nucleotide sequences of lipA (936 bp) and lipB (1023 bp) had been deposited in the GenBank database under accession numbers JN594060 and JN594061, respectively.

\section{Expression of the lipase using different expression plasmid systems}

In this work, three expression plasmids, one single expression plasmid pET28a and two dual expression plasmids pACYCDuet-1 and pETDuet-1, were investigated for high level expression of the active lipase. pACYCDuet-1 and pETDuet-1 are both designed for the coexpression of two target genes. Each of the vectors contains two multiple cloning sites (MCS), and each of which is preceded by a T7 promoter/lac operator and ribosome binding site (rbs) [19]. The vector pACYCDuet-1 carries the P15A replicon, lacI gene and chloramphenicol resistance gene. While the vector pETDuet-1 carries the pBR322-derived ColE1 replicon, lacI gene and ampicillin resistance gene. pACYCDuet-1 and pETDuet- 1 can be used in combination in an appropriate host strain for the coexpression of up to 4 target genes.

Three different expression plasmids pACYCDuet-lipAlipB, pETDuet-lipA-lipB and pET28a-lipAB contained lip $A$, lip $B$ or lip $A B$ genes were successfully constructed. The structure schematic diagram was shown in the Figure 2.

The three recombinant plasmids were transferred into E.coli BL21 (DE3) and expressed under the control of T7 promoter, respectively. Upon induction with $0.5 \mathrm{mM}$ IPTG for $20 \mathrm{~h}$ at $20^{\circ} \mathrm{C}$, the cells were collected by centrifugation and disrupted by sonication. Both polypeptides
LipA (35 KDa) and LipB (38 KDa) were expressed as shown in SDS-PAGE gel (Figure 3).

The whole cell expression level of LipA was almost the same in the three expression plasmid systems $E$. coli BL21/pET28a-lipAB (Figure 3A, lane1), E. coli BL21/ pETDuet-lipA-lipB (Figure 3B, lane 1) and E. coli BL21/ pACYCDuet-lipA-lipB (Figure 3C, lane 1) in the same condition. However, the active LipA level in the whole cell lysate's supernatant was obviously different among the three expression plasmid systems. The amount of active LipA expressed by the $E$. coli BL21/pET28a-lipAB (Figure 3A, lane2) and the E. coli BL21/pETDuet-lipAlipB (Figure 3B, lane 2) was less than that of the $E$. coli BL21/pACYCDuet-lipA-lipB (Figure 3C, lane 2). The expression level of LipB was also significantly different among the three expression plasmid systems. The amount of the LipB expressed by the E. coli BL21/ pACYCDuet-lipA-lipB (Figure 3C) was much more than those of the other two expression plasmid systems. The lipase activity of different recombinant $E$. coli cell lysate's supernatants containing active lipase was also determined. The result showed that the activity of plasmid pET28a-lip $A B$ system was only $1300 \mathrm{U} / \mathrm{L}$, and the activity of plasmid pETDuet-lipA-lipB system was $3200 \mathrm{U} / \mathrm{L}$, but that of plasmid pACYCDuet-lipA-lipB system could up to $8500 \mathrm{U} / \mathrm{L}$, which was more than six times than the single expression plasmid pET28a-lipAB system. These results indicated that LipB was essential for the production of active LipA, which was agreement with many other reports. Gerritse et al. [20] found that the expression level of the LipB played a key role in the expression and secretion of the active lipase when the copy number of the plasmid carrying the exogenous gene was more than 10, and only when the LipB expression amount was raised, the activity of the lipase could be improved. Also, Quyen et al. [21] reported that the active lipase was negligible when the coexpressed chaperone LipB in the gene cluster was expressed at a negligible level in comparison to the LipA.

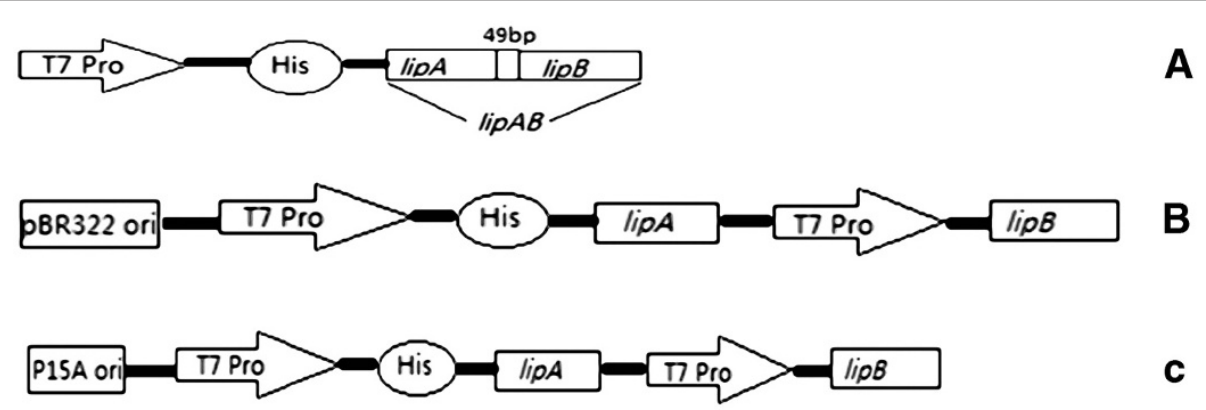

Figure 2 Schematic representation of the expression cassettes. (A) pET28a-lipAB; (B) pETDuet-lipA-lipB; (C) pACYCDuet-lipA-lipB. T7 Pro, T7 promoter; His, $6 \times$ His tag; P15A ori, P15A origin; pBR322 ori, pBR322 origion; lipA, mature lipase gene; lipB, the complete chaperone gene; lipAB, the gene contained both $\operatorname{lip} A$ and $\operatorname{lip} B$. 


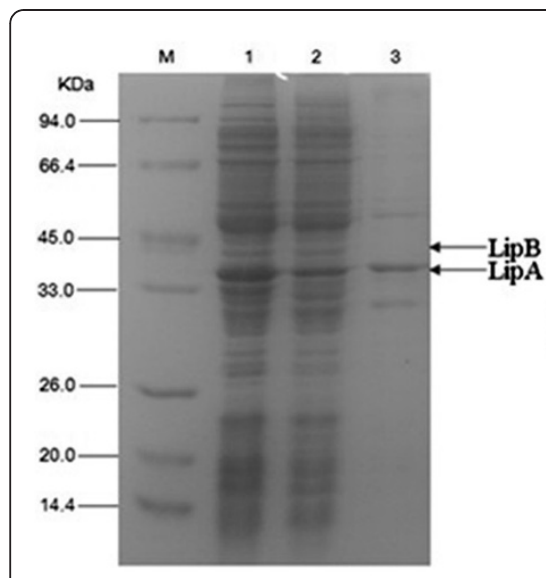

A

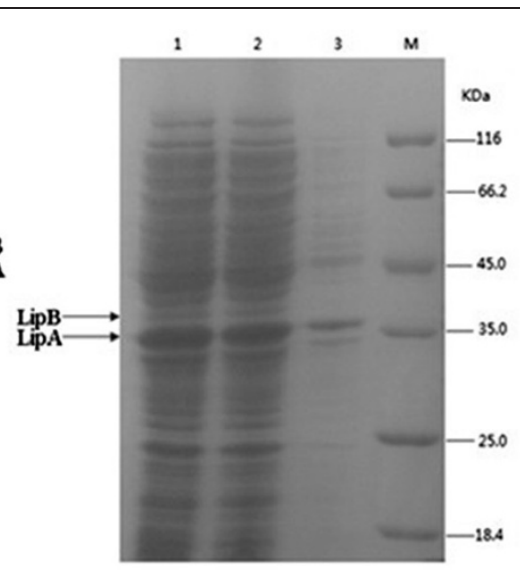

B

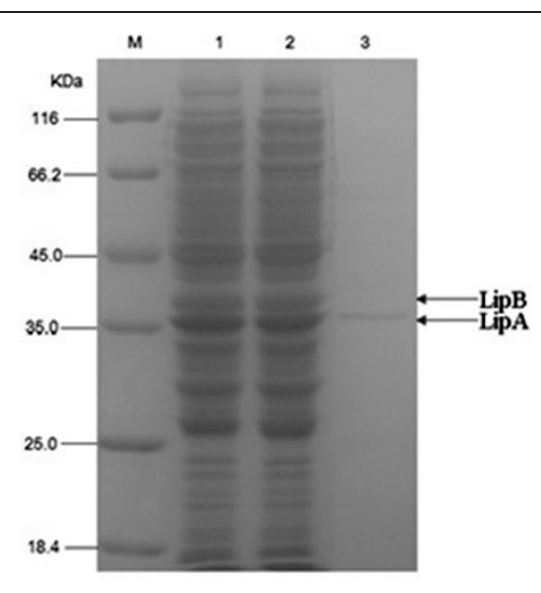

C

Figure 3 SDS-PAGE gel stained with Coomassie brilliant blue R-250 showing expression of recombinant proteins. (A) M, Protein

molecular weight marker. Lane 1, pET28a-lipAB whole cell lysate. Lane 2, cell lysate's supernatant. Lane 3, cell lysate's precipitate; (B) M, Protein molecular weight marker. Lane 1, pETDuet-lipA-lipB whole cell lysate. Lane 2, cell lysate's supernatant. Lane 3, cell lysate's precipitate; (C) M, Protein molecular weight marker. Lane 1, pACYCDuet-lipA-lipB whole cell lysate. Lane 2, cell lysate's supernatant. Lane 3, cell lysate's precipitate.

The ratio of lipase and chaperone was important to the lipase activity. Traub et al. [22] reported that the lipase and chaperone must be present in equimolar amounts to obtain optimal refolding efficiency. Akbari et al. [17] also reported that the concentration of lipase and foldase was an important parameter affecting refolding process. In this work, the SDS-PAGE showed that the concentration of LipA and LipB was in a more equal proportion in pACYCDuet-lipA-lipB system than those of pETDuet-lipA-lipB system and pET28a-lipAB system (Figure 3A-C). Therefore, the LipA expressed by pACYCDuet-lipA-lipB system could be more refolded into active conformation. This can explain the result that the lipase activity expressed by pACYCDuet-lipA-lipB system was more than those of pETDuet-lipA-lipB system and pET28a-lipAB system in the same condition.

In addition, the two dual expression plasmids pACYCDuet-1 and pETDuet-1 have different replicons, so they can be recombined in the same host strain for the overexpression of target genes. In this work, the two plasmids pACYCDuet-lipA-lipB and pETDuet-lipA-lipB were transferred into the same $E$. coli BL21 to hope further improvement of the LipA and LipB expression. After induction with IPTG, the activity of the lipase expressed by E. coli BL21/pACYCDuet-lipA-lipB + pETDuet-lipA-lipB was only $3000 \mathrm{U} / \mathrm{L}$, which was lower than that of E. coli BL21/pETDuet-lipA-lipB or E. coli BL21/ pACYCDuet-lipA-lipB single plasmid system. The copy number of pACYCDuet-lipA-lipB or/and pETDuet-lipA$\operatorname{lip} B$ may decrease when the two plasmids existed in the same host strain.

As previously reported, the gene regulatory and secretion mechanisms were complex by coexpression of lipase and its special foldase in an expression vector. In this work, two dual expression plasmids systems were used to enhance the expression amount of the LipB in E. coli in order to obtain more active lipase in vivo. The result showed that the dual expression plasmids could obviously increase the expression level of active lipase. But different dual expression plasmid showed different effect, and the plasmid pACYCDuet-1 was more suitable for the co-expression LipA and LipB than the plasmid pETDuet-1. So far, only Quyen et al. [18] had chose a dual expression plasmid system to express an active lipase, but the dual expression plasmid was derived from pET22b and its construction process was complex. The dual expression plasmids pACYCDuet-1 and pETDuet-1 were both the commercial plasmids, which were more convenient for practical application.

\section{Characterization of the lipase}

To examine the properties of the lipase produced by E. coli BL21/pACYCDuet-lipA-lipB, the recombinant lipase was purified to homogeneity (more than 95\%) using nickel affinity chromatography (Ni-NTA) by exploiting the histidine tag.

The optimum $\mathrm{pH}$ of the lipase was found to be 9.0, and the enzyme activity was also relatively high at the $\mathrm{pH}$ range of 8-10 (Figure 4). The lipase showed good $\mathrm{pH}$ stability, and more than $70 \%$ of the original activity could be retained at the $\mathrm{pH}$ range of 6-10 (Figure 4). The optimum $\mathrm{pH}$ and $\mathrm{pH}$ stability revealed that the lipase should be alkaline in nature. Lipases from other Pseudomonas sp. such as P. mendocina PK-12CS [23] and $P$. aeruginosa [24] had also been reported to possess good stability over wide $\mathrm{pH}$ range. 


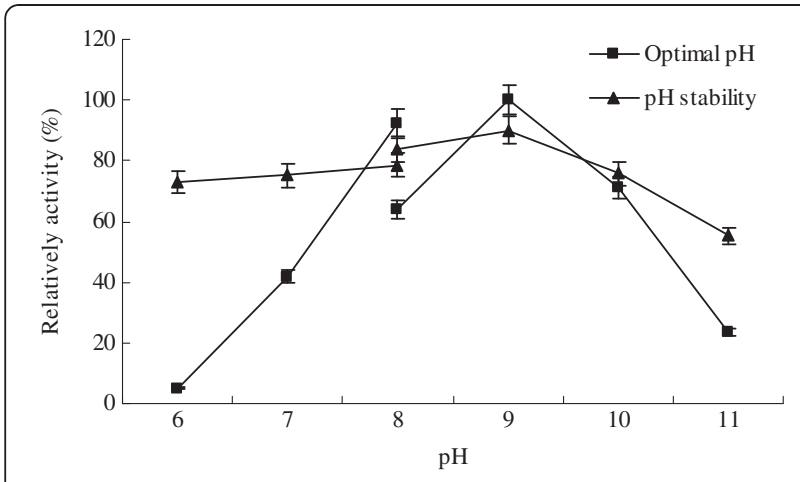

Figure 4 Effect of the $\mathrm{pH}$ on the lipase activity and stability. The highest lipase activity was $129 \mathrm{U} / \mathrm{ml}$ and set to $100 \%$.

The optimal temperature of the lipase was observed to be $30^{\circ} \mathrm{C}$ (Figure $5 \mathrm{~A}$ ), which showed that this lipase was a low temperature enzyme. The thermal stability of the lipase was poor. Although the enzyme activity had almost no change with the extension of time at $30^{\circ} \mathrm{C}$, it declined intensively at $40^{\circ} \mathrm{C}$, and there was only less than $40 \%$ of the original activity retained at $90 \mathrm{~min}$. When the temperature was above $50^{\circ} \mathrm{C}$, the enzyme activity lost seriously only after 15 min (Figure $5 \mathrm{~B}$ ).

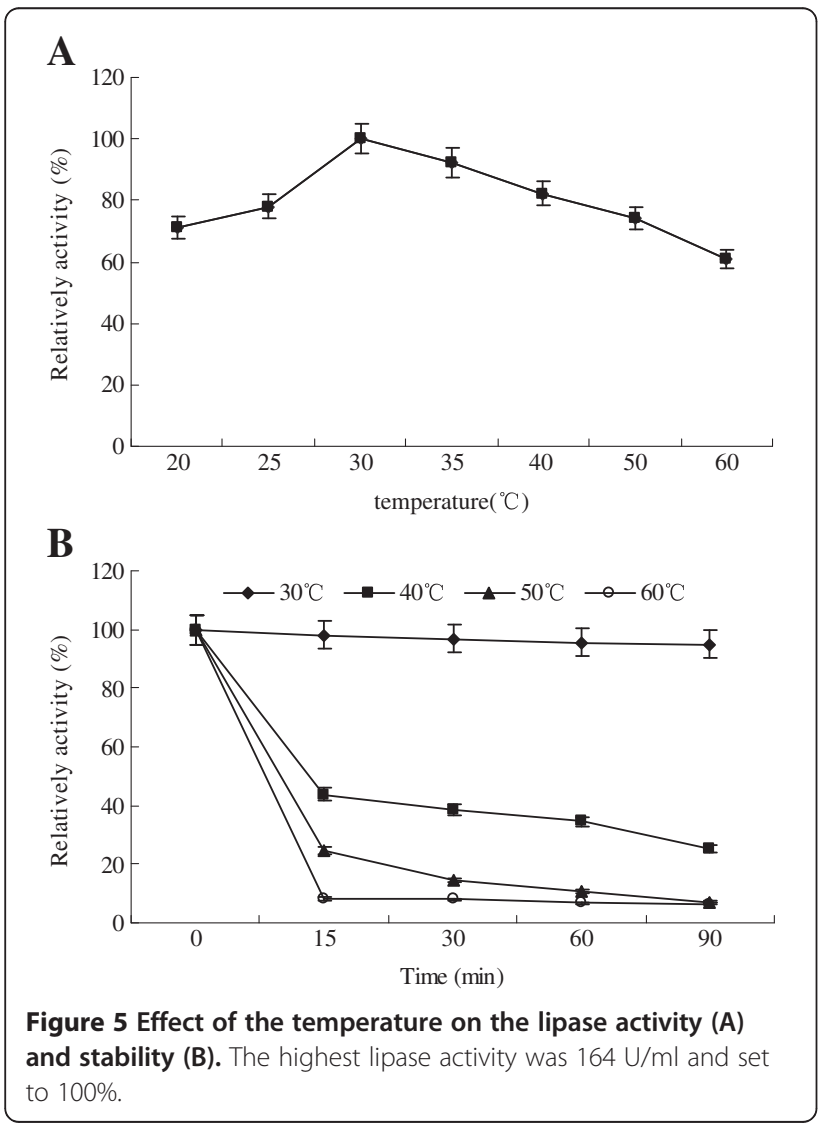

The lyophilized lipase catalyzed the esterification reaction between butyric acid and hexanol was first investigated. An obvious peak appeared through GC analysis, and was identified as butyric acid hexyl ester. This indicated that the lipase could catalyze the esterification reaction. The optimum substrate alcohol and fatty acid for this lipase catalyzed esterification reaction were further investigated. The result was shown in Figure 6. Medium chain alcohols were appropriate with hexanol as the optimal alcohol (Figure 6A). The optimal fatty acid was octylic acid, and the 10 to 16 carbon acid was also fine, which meant that the lipase was suitable to catalyze the esterification of long chain fatty acids (Figure 6B).

\section{Conclusions}

In this work, a lipase-producing strain identified as $P$. aeruginosa was isolated through the screening procedure. The lipase gene $\operatorname{lip} A$ (936 bp) and lipase specific foldase gene lipB (1023 bp) were cloned from the P.aeruginosa. Three heterologous expression systems were established for the expression of active lipase in vivo. The plasmid pACYCDuet-lipA-lipB was the optimal expression plasmid among the three expression plasmids constructed in this work, and the lipase activity produced by $E$. coli BL21/pACYCDuet-lipA-lipB could be up to $8500 \mathrm{U} / \mathrm{L}$. The lipase had an optimal temperature of $30^{\circ} \mathrm{C}$ and an optimal pH of 9. The lipase showed obvious
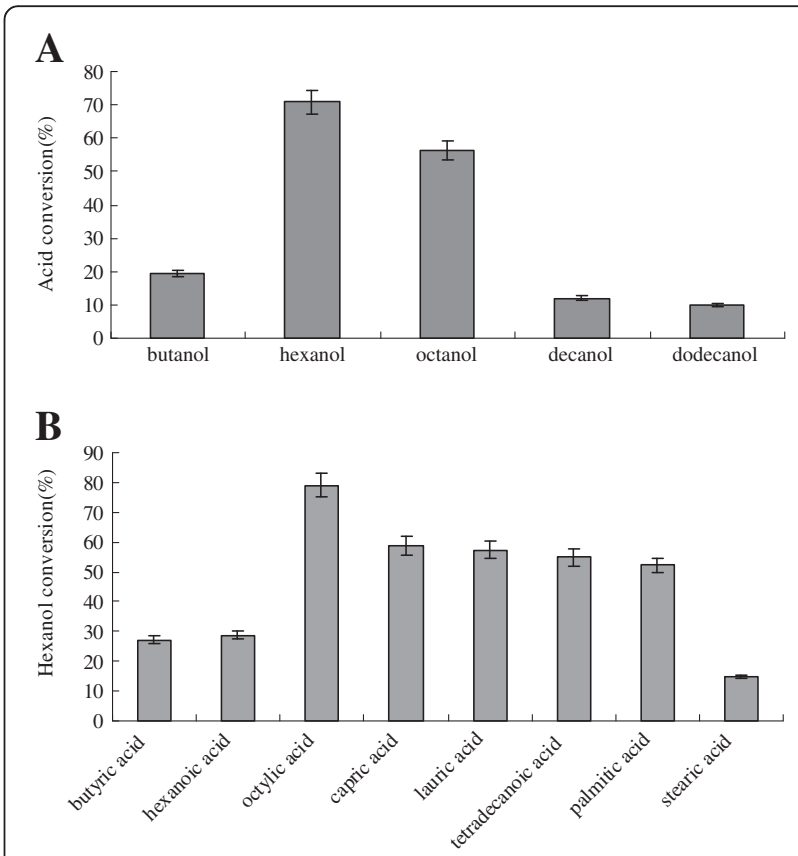

Figure 6 The optimum substrate alcohol and fatty acid for lipase catalyzed esterification reaction. (A) The optimal alcohol; (B) The optimal fatty acid. 
esterification activity and thus had potential biocatalytic applications.

\section{Methods \\ Materials}

Restriction enzymes, T4 DNA ligase, and Taq polymerase premix were supplied by MBI Fermentas (Germany). The DNA gel extraction and plasmid extraction were purchased from Generay Biotech (Shanghai) Co., Ltd. Peptone and yeast extract were obtained from Oxoid. All reagents were of analytical grade unless otherwise stated.

\section{Strains, plasmids and cultured conditions}

Soil samples were collected from oil-rich soil near restaurants or residential area. E. coli $\mathrm{DH} 5 \alpha$ was used for transforming and cloning recombinant plasmids, and E. coli BL21 (DE3) was used as a host for gene expression. Plasmids pET28a, pACYCDuet-1 and pETDuet-1 preserved in our laboratory were used for the construction of the expression systems. The antibiotic concentrations used for the optimum growth of strains were $100 \mu \mathrm{g} / \mathrm{ml}$ of ampicillin, $50 \mu \mathrm{g} / \mathrm{ml}$ of kanamycin and $100 \mu \mathrm{g} / \mathrm{ml}$ of chloramphenicol. E. coli was cultured at $37^{\circ} \mathrm{C}$ in Luria-Bertani medium (LB) supplemented with antibiotics. Protein expression was induced by the addition of $0.5 \mathrm{mM}$ IPTG to the growth medium.

\section{Isolation of lipase-producing strain}

LB medium added with $1 \%$ olive oil emulsion was used as enrichment medium. The culture was repeatedly transferred to fresh medium for three times. Then, samples of the culture were diluted and spread on Rhodamine B agar plates (yeast extract $0.5 \%$, tryptone $1 \%, \mathrm{NaCl} 1 \%$, olive oil $1 \%$, Rhodamine B $0.001 \%$ and agar $1.5 \%$ ). The plates were incubated at $37^{\circ} \mathrm{C}$ for $48 \mathrm{~h}$. The microbes showing obviously red hydrolysis circle were pointed on the new Rhodamine B agar plates. The ones showing high ratios of red hydrolysis circle were selected as potential lipase producers and identified by means of $16 \mathrm{~S}$ rDNA.

\section{DNA manipulations}

Chromosomal DNA of the screened strain was obtained from cells grown in $\mathrm{LB}$ medium at $200 \mathrm{rpm}$ at $37^{\circ} \mathrm{C}$ for $24 \mathrm{~h}$ as described by Ausubel et al. [25] with some modification, as the precipitation of DNA was carried out using ethanol instead of isopropanol. Plasmid DNA was isolated by alkaline lysis method [26]. The oligonucleotide primers used in this study were synthesized by Generay Biotech (Shanghai) Co., Ltd.

\section{Cloning of lipase and lipase specific foldase genes}

The genomic DNA from the screened $P$. aeruginosa AB was used as a source of lipase and lipase specific foldase genes. PCR primers (Table 1) for the lipase and lipase specific foldase genes were designed based on the fulllength DNA sequences reported for $P$. aeruginosa lipase and foldase genes in NCBI GenBank.

For cloning the lipase gene lipA and lipase specific foldase gene $l i p B$, following oligonucleotides in the Table 1 were used for PCR amplification. Each reaction mixture $(50 \mu \mathrm{l})$ contained premix $25 \mu \mathrm{l}, \mathrm{dd}_{2} \mathrm{O} 22 \mu \mathrm{l}$, sense primer $(20 \mu \mathrm{M}) 1 \mu \mathrm{l}$, antisense primer $(20 \mu \mathrm{M}) 1 \mu \mathrm{l}$ and genomic DNA $1 \mu \mathrm{l}$. While the gene named lip $A B$ contained both $\operatorname{lip} A$ and $\operatorname{lip} B$ had a higher $\mathrm{G}+\mathrm{C}$ content than the usual gene, $2 \mu \mathrm{l}$ DMSO was added to the reaction mixture. The PCR for lipA consisted of an initial denaturation for $5 \mathrm{~min}$ at $94^{\circ} \mathrm{C}$. Thirty cycles were run, and each cycle consisted of $1 \mathrm{~min}$ of denaturation at $94^{\circ} \mathrm{C}$, $45 \mathrm{~s}$ of annealing at $60^{\circ} \mathrm{C}$ and $1 \mathrm{~min}$ of extension at $72^{\circ} \mathrm{C}$ followed by a final extension of $10 \mathrm{~min}$ at $72^{\circ} \mathrm{C}$. For amplification of $l i p B$, annealing temperature was $53^{\circ} \mathrm{C}$. For amplification of the gene lipAB contained both lipA and lipB, step down PCR programme was run, which consisted of six steps with annealing temperature declined from $65^{\circ} \mathrm{C}$ to $55^{\circ} \mathrm{C}$ at the interval of $2^{\circ} \mathrm{C}$. All of the resultant PCR products were then ligated with plasmid pMD19-T, respectively. The constructed plasmids T-lipA, T-lipB and T-lipAB were sequenced by BGI and blasted on NCBI.

\section{Construction of the expression plasmids}

The constructed plasmid T-lipA which contained lipA gene was digested with BamHI and HindIII and ligated

Table 1 Primers used in this work (F: forward primer, R: reverse primer)

\begin{tabular}{lrc}
\hline Primers & Sequence $\mathbf{( 5}^{\prime} \mathbf{- 3}^{\prime} \mathbf{)}$ & Source \\
\hline A-F & GGATCCATGAAGAAGAAGTCTCTGCT & Amplification of lipA, BamHI site \\
A-R & AAGCTTCTACAGGCTGGCGTCTT & Amplification of lipA, Hindlll site \\
B-F & GGGCATATGGTGAAGAAATCCTCCTG & Amplification of lipB, Ndel site \\
B-R & CTCGAGTCAGCGCTGCTCGGCCT & Amplification of lipB, Xhol site \\
AB-F & CCTTGGATCCATGAAGAAGAAGTCTCTGCTCC & Amplification of lipAB, BamHI site \\
AB-R & CCTTAAGCTTCAGCTGCTCGGCCTGGCGCAT & Amplification of lipAB, Hindlll site \\
\hline
\end{tabular}


into similarly digested pACYCDuet-1 and pETDuet-1 vectors using T4 DNA ligase, respectively. The reconstructed plasmids were named as pACYCDuet-lipA and pETDuet-lipA, respectively. Similarly, the constructed plasmid T-lipB which contained $\operatorname{lip} B$ gene was digested with $N d e I$ and $X h o I$ and ligated into similarly digested pACYCDuet-lipA and pETDuet-lipB vectors using T4 DNA ligase, respectively. The re-constructed plasmids were named as pACYCDuet-lipA-lipB and pETDuet-lipA$l i p B$, respectively (see the Additional file 1 (B) and (C) genetic maps). The constructed plasmid T-lipAB which contained both $\operatorname{lip} A$ and $\operatorname{lip} B$ was digested with $B a m \mathrm{HI}$ and HindIII and ligated into similarly digested pET28a. The re-constructed plasmid was named as pET28a-lipAB (see the Additional file 1 (A) genetic map). The construction process of the recombinant plasmid pACYCDuetlipA-lipB was shown in the Additional file 2. The other two recombinant plasmids were also constructed through the similarly process.

Competent E. coli $\mathrm{DH} 5 \alpha$ cells prepared by $\mathrm{CaCl}_{2}$ method were transformed using the heat shock and cold treatment [25]. All the transformed colonies were screened by colony PCR followed by double digestion of the constructed plasmid.

\section{Functional expression of recombinant lipase in $E$. coli}

All the recombinant plasmids were transformed into E. coli BL21 (DE3) for protein overexpression. The transformants were grown in LB medium added with the corresponding antibiotic at $37^{\circ} \mathrm{C}$ and $200 \mathrm{rpm}$. When the optical density (OD) at $600 \mathrm{~nm}$ reached about 0.8 , IPTG was added to a final concentration of $0.5 \mathrm{mM}$. Incubation at $20^{\circ} \mathrm{C}$ for a further $20 \mathrm{~h}$, cells were harvested by centrifugation $(8,000 \mathrm{rpm}, 5 \mathrm{~min}$ at $\left.4^{\circ} \mathrm{C}\right)$. The pellet was washed with $50 \mathrm{mM}$ Tris $-\mathrm{HCl}$ buffer ( $\mathrm{pH} \mathrm{8.0)}$ and was resuspended in $10 \mathrm{ml}$ of the same buffer. The cells were then disrupted by sonication at the power controlled from $200 \mathrm{~W}$ to $400 \mathrm{~W}$, and each circle worked $4 \mathrm{~s}$ and intermitted $5 \mathrm{~s}$, continued $20 \mathrm{~min}$. Bacterium fluid should be held in ice bath during the sonication to prevent protein denaturation. The cell lysate was centrifuged at 10,000 rpm for $10 \mathrm{~min}$. The supernatant was collected as soluble fraction, while the pellet was taken as the insoluble fraction and resuspended in an equal volume of Tris- $\mathrm{HCl}$ buffer ( $\mathrm{pH} 8.0)$.

In order to detect the recombinant protein, $20 \mu \mathrm{l}$ of samples were analyzed by sodium dodecyl sulfate (SDS) gel electrophoresis (GE) as described by Laemmli [27]. Proteins were stained with Coomassie Brilliant Blue $\mathrm{R}-250$. The soluble fraction which contained active lipase was subjected to activity determination by alkali titration method.

\section{Determination of the lipase activity}

Two methods were adopted to determine the lipase activity in this work. One method estimated the free fatty acid by alkali titration using olive oil as the substrate [28]. $1 \mathrm{ml}$ enzyme solution was added to the substrate solution containing $5 \mathrm{ml}$ of $10 \%$ emulsified olive oil in $10 \%$ gum acacia and $2.5 \mathrm{ml}$ of $0.2 \mathrm{~mol} / \mathrm{L}$ Tris- $\mathrm{HCl}$ buffer $(\mathrm{pH}$ 8.0). The enzyme-substrate solution was incubated on water bath shaker at $30^{\circ} \mathrm{C}$ and $150 \mathrm{rpm}$ for $10 \mathrm{~min}$. $10 \mathrm{ml}$ ethanol was added to stop the reaction. Liberated fatty acids were titrated with $0.05 \mathrm{~mol} / \mathrm{L} \mathrm{NaOH}$ using phenolphthalein as indicator. One unit (U) was defined as the amount of enzyme that released $1 \mu \mathrm{mol}$ fatty acid per minute under the standard assay conditions. This method was used to determine the expressed lipase activity of different recombinant $E$. coli.

The other method determined the liberated $p N P$ using para-nitrophenyl palmitate $(p N P P)$ as substrate [29] with slight modifications. The $p$ NPP was dissolved in 2-propanol to make the concentration of $3 \mathrm{mg} / \mathrm{ml}$. The substrate solution consisted of $0.1 \mathrm{ml}$ of $p \mathrm{NPP}$ solution and $2.8 \mathrm{ml}$ Tris- $\mathrm{HCl}$ buffer $(20 \mathrm{mM}, \mathrm{pH} 8)$. The reaction was carried out at $30^{\circ} \mathrm{C}$ by adding $0.1 \mathrm{ml}$ appropriately diluted enzyme solution to the substrate solution preincubated at $30^{\circ} \mathrm{C}$ for $5 \mathrm{~min}$, and incubation was continued for further $5 \mathrm{~min}$. The test tubes were immersed in ice till the optical density was taken at $405 \mathrm{~nm}$. One unit (U) was defined as the amount of enzyme that liberated $1 \mu \mathrm{mol} p \mathrm{NP}$ per minute under the standard assay conditions. This method was used to assay the characterization of lipase.

\section{Characterization of lipase}

The optimum $\mathrm{pH}$ for the purified lipase was evaluated over a pH range from 6.0 to 11.0 under the standard assay procedures. $20 \mathrm{mM}$ of sodium phosphate buffer (pH6.0-8.0) and borax buffer (8.0-11.0) were used. The $\mathrm{pH}$ stability of the lipase was investigated at $30^{\circ} \mathrm{C}$ by preincubation of the enzyme solutions in the described buffer systems in the absence of substrate for $30 \mathrm{~min}$. The reaction mixture was then subjected to the standard assay procedures and a $\mathrm{pH}$ profile was produced with the enzyme activity at the optimum $\mathrm{pH}$ set to $100 \%$.

The optimum temperature for the purified lipase was measured at various temperatures $\left(20-50^{\circ} \mathrm{C}\right)$ under standard assay procedures. A temperature profile was produced with the enzyme activity at the optimum temperature set to $100 \%$. The thermostability of the lipase was investigated by preincubating the enzyme solutions at various temperatures $\left(20-50^{\circ} \mathrm{C}\right)$ for $15,30,60$ and $90 \mathrm{~min}$, respectively. The residual lipase activity of the samples was then assayed under standard assay procedures. 
In order to investigate the esterification characterization of the lipase, the purified lipase was lyophilized for $12 \mathrm{~h}$, and the dried powder was used as the lipase catalyst. The reaction mixture contained $1 \mathrm{mmol}$ alcohol, $1 \mathrm{mmol}$ fatty acid and $5 \mathrm{ml} n$-hexane. $5.0 \mathrm{mg}$ lipase powder was added into the reaction mixture and the reaction was carried out at $30^{\circ} \mathrm{C}$ for $8 \mathrm{~h} .1 \mathrm{ml}$ of reaction liquid was centrifuged at $8000 \mathrm{rpm}$ for $5 \mathrm{~min}$, and the supernatant was for gas chromatography (GC) analysis. The product was identified by GC-MS. Butanol, hexanol, octanol, decanol and dodecanol were selected to esterify with hexanoic acid for optimum alcohol substrate investigation. Butyric acid, hexanoic acid, octylic acid, capric acid, lauric acid, tetradecanoic acid, palmitic acid and stearic acid were selected to esterify with hexanol for optimum fatty acid substrate investigation. GC analysis was performed on an Agilent 6890 Gas Chromatograph equipped with a flame ionization detector (FID) and a HP-5 capillary column (5\% phenyl methyl siloxane capillary, $30.0 \mathrm{~m} \times 320 \mu \mathrm{m} \times 0.25 \mu \mathrm{m}$ nomimal). The column temperature was kept at $60^{\circ} \mathrm{C}$ for $0.5 \mathrm{~min}$, heated to $220^{\circ} \mathrm{C}$ at $10^{\circ} \mathrm{C} / \mathrm{min}$. The temperatures of the injector and detector were set at $250^{\circ} \mathrm{C}$.

\section{Additional files}

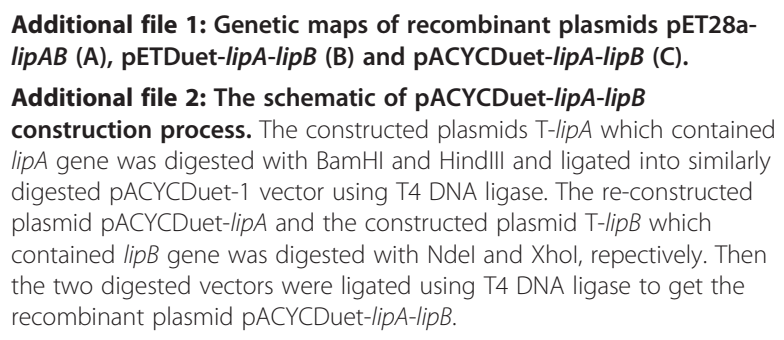

\section{Competing interests}

The authors declare that they have no competing interests.

\section{Authors' contributions}

XPW and JJX performed the cloning and expression of lipase. XPW and EZS drafted the manuscript. PYY performed the characterization of lipase and revision of the manuscript. BG commented on and polished the manuscript. EZS and DZW supervised the study. All authors read and approved the final manuscript.

\section{Acknowledgements}

This work was supported by the Open Funding Project of the State Key Laboratory of Bioreactor Engineering, the Fundamental Research Funds for the Central Universities and the Specialized Research Fund for the Doctoral Program (New Teachers) of Higher Education (20090074120015).

Received: 4 June 2012 Accepted: 3 September 2012 Published: 6 September 2012

\section{References}

1. Jaeger KE, Ransac S, Dijkstra BW, Colson C, van Heuvel M, Misset O: Bacterial lipases. FEMS Microbiol Rev 1994, 15(1):29-63.

2. Reetz MT: Lipases as practical biocatalysts. Curr Opin Chem Biol 2002, 6(2):145-150.

3. Jaeger KE, Eggert T: Lipases for biotechnology. Curr Opin Biotechnol 2002, 13(4):390-397
4. Fujii R, Nakagawa Y, Hiratake J, Sogabe A, Sakata K: Directed evolution of Pseudomonas aeruginosa lipase for improved amide-hydrolyzing activity. Protein Eng Des Sel 2005, 18(2):93-101.

5. Kato K, Tanaka S, Fujii S, Katayama M, Kimoto H: Preparation of optically active trifluoromethylated ( 3 -indolyl) thiacarboxylic acids, novel plant growth regulators, through lipase-catalyzed enantioselective hydrolysis. J Biosci Bioeng 1999, 87(1):76-81.

6. Liebeton K, Zonta A, Schimossek K, Nardini M, Lang D, Dijkstra BW, Reetz MT, Jaeger KE: Directed evolution of an enantioselective lipase. Chem Biol 2000, 7(9):709-718.

7. Arpigny $J$, Jaeger KE: Bacterial lipolytic enzymes: classification and properties. Biochem J 1999, 343:177-183.

8. Rosenau F, Tommassen J, Jaeger KE: Lipase-specific foldases. Chembiochem 2004, 5(2):152-161.

9. Jorgensen ST, Skov KW, Diderichsen B: Cloning, Sequence, and expression of a lipase gene from Pseudomonas cepacia: lipase production in heterologous hosts requires two Pseudomonas genes. J Bacteriol 1991, 173(2):559-567.

10. Oshima-Hirayama N, Yoshikawa K, Nishioka T, Oda J: Lipase from Pseudomonas aeruginosa production in Escherichia coli and activation in vitro with a protein from the downstream gene. Eur J Biochem 1993. 215(2):239-246.

11. Hobson AH, Buckley CM, Aamand JL, Jorgensen ST, Diderichsen B, Mcconnell DJ: Activation of a bacterial lipase by its chaperone. P Natl Acad Sci USA 1993, 90(12):5682-5686.

12. Yang JH, Kobayashi $K$, Iwasaki $Y$, Nakano $H$, Yamane $T$ : In vitro analysis of roles of a disulfide bridge and a calcium binding site in activation of Pseudomonas sp. strain KWI-56 lipase. J Bacteriol 2000, 182(2):295-302.

13. Rosenau F, Jaeger KE: Bacterial lipases from Pseudomonas: regulation of gene expression and mechanisms of secretion. Biochimie 2000, 82(11):1023-1032.

14. Frenken LGJ, Groot AD, Tommassen J, Verrips CT: Role of the lipB gene product in the folding of the secreted lipase of Pseudomonas glumae. Mol Microbiol 1993, 9(3):591-599.

15. Ihara F, Okamoto I, Akao K, Nihira T, Yamada Y: Lipase modulator protein (LimL) of Pseudomonas sp. strain 109. J Bacteriol 1995, 177(5):1254-1258.

16. Madan B, Mishra P: Co-expression of the lipase and foldase of Pseudomonas aeruginosa to a functional lipase in Escherichia coli. Appl Microbiol Biot 2010, 85(3):597-604.

17. Akbari N, Khosro K, Rezaie S, Mirdamadi S, Shavandi M, Ghaemi N: High-level expression of lipase in Escherichia coli and recovery of active recombinant enzyme through in vitro refolding. Protein Expres Purif 2010, 70(1):75-80.

18. Quyen TD, Vu CH, Le GTT: Enhancing functional production of a chaperone-dependent lipase in Escherichia coli using the dual expression cassette plasmid. Microb Cell Fact 2012, 11:29.

19. Novy R, Yaeger $K$, Held D, Mierendorf R: Coexpression of multiple target proteins in E. coli. Innovations 2002, 15:2-6.

20. Gerritse G, Ronald WJH, Quax WJ: Development of a Lipase fermentation process that uses a recombinant Pseudomonas alcaligenes strain. Appl Environ Microb 1998, 64(7):2644-2651.

21. Quyen DT, Le GTT, Nguyen TT, Oh TK, Lee JK: High-level heterologous expression and properties of a novel lipase from Ralstonia sp. M1. Protein Exp Purif 2005, 39(1):97-106.

22. Traub PC, Schmidt-Dannert C, Schmitt J, Schmid RD: Gene synthesis, expression in E. coli, and in vitro refolding of Pseudomonas sp. KWI 56 and Chromobacterium viscosum lipases and their chaperones. Appl Microbiol Biot 2001, 55(2):198-204.

23. Jinwal UK, Roy U, Chowdhury AR, Bhaduri AP, Roy PK: Purification and characterization of an alkaline lipase from a newly isolated Pseudomonas mendocina PK-12CS and chemoselective hydrolysis of fatty acid ester. Bioorg Med Chem 2003, 11(6):1041-1046.

24. Karadzic I, Masui A, Zivkovic LI, Fujiwara N: Purification and characterization of an alkaline lipase from Pseudomonas aeruginosa isolated from putrid mineral cutting oil as component of metalworking fluid. J Biosci Bioeng 2006, 102(2):82-89.

25. Ausubel FM, Brent R, Kingston RE, Moore DD, Seidman JG, Smith JA, Struhl K: Current protocols in molecular biology, Volume 1. 2nd edition. New York: Wiley; 1987

26. Sambrook J, Fritsch E, Maniatis T: Molecular cloning: a laboratory manual. Cold Spring Harbor Laboratory Press: Cold Spring Harbor; 1989. 
27. Laemmli UK: Cleavage of structure proteins during the assembly of the head of bacteriophage T4. Nature 1970, 227:680-685.

28. Borkar PS, Bodade RG: Purification and characterization of extracellular lipase from a new strain-Pseudomonas Aeruginosa SRT 9. Braz J Microbio 2009, 40:358-366.

29. Winkler UK, Stuckmann M: Glycogen, hyaluronate and some other polysaccharides greatly enhance the formation of exolipase by Serratia marcescens. J Bacteriol 1979, 138(3):663-670.

doi:10.1186/1472-6750-12-58

Cite this article as: Wu et al:: In vivo functional expression of a screened $P$. aeruginosa chaperone-dependent lipase in E. coli. BMC Biotechnology 2012 12:58.

\section{Submit your next manuscript to BioMed Central and take full advantage of:}

- Convenient online submission

- Thorough peer review

- No space constraints or color figure charges

- Immediate publication on acceptance

- Inclusion in PubMed, CAS, Scopus and Google Scholar

- Research which is freely available for redistribution 